\author{
Análytical results for stream sediments, pan concentrates \\ from stream sediments, and rock samples collected from \\ the Stensgar Mountain quadrangle, \\ Stevens County, Washington
}

\author{
by \\ James G. Evans ${ }^{1}$ \\ and \\ Jocelyn A. Peterson ${ }^{2}$ \\ Open-File Report $87-74$
}

This report is preliminary and has not been reviewed for conformity with

U.S. Geological Survey editorial standards and stratigraphic nomenclature. ${ }^{1}$ spokane, WA.

2 Menlo Park, CA. 
The Stensgar Mountain quadrangle is located in Stevens County, Wash., 70 $\mathrm{km}$ north-northwest of Spokane and $10 \mathrm{~km}$ west of Valley (fig. 1). The northeast-trending magnesite belt, of Weaver (1920, p. 319) passes through the quadrangle. Magnesite is not presently an economic commodity in the area. Small deposits of barite, copper minerals and antimony also occur in the quadrangle (Campbell and Loofbourow, 1962). Gold was found at the Wells Fargo mine during this study.

The quadrangle contains a section of Middle proterozoic Deer Trail Group at least $4,000 \mathrm{~m}$ thick, a section of Middle to Late Proterozoic Windermere Group as much as 1,700 in thick, and Lower Cambrian Addy Quartzite and old Dominion Limestone totalling 2,600 m thick (fig. 2; Evans, 1986). The Deer Trail Group consists of, from oldest to youngest: (1) Togo Formation (slate, siltite, quartzite), (2) Edna Dolomite, (3) McHale Slate, (4) Stensgar Dolomite, and (5) Buffalo Hump Formation (slate, quartzite, conglomerate). The Windermere Group consists of the Huckleberry Formation (basal conglomerate member and upper member of metabasalt and metatuff), and isonk Formation (slate, conglomerate, dolomite). Gabbro and metabasalt feeder dikes for the flows of the Huckleberry Formation caused minor contact metamorphism where they intruded the Deer Trail Group and conglomerate of the Huckleberry Formation. Lower Cambrian Addy Quartzite was deposited unconformably on the Proterozoic rocks and was subsequently covered by a thick section of old Dominion Limestone, most of which is not present in the quadrangle. All of the rocks were subjected to low-grade burial metamorphism, which decreases in grade and intensity upwards. The entire section of the Deer Trail Group appears to lie within a Mesozoic duplex thrust (fig. 2), with the Lane Mountain thrust as the floor thrust and the stensgar Mountain thrust as the 
roof thrust. Low-grade dynamothermal metamorphism accompanied thrusting and greatly affected the entire section of the Deer Trail Group and the conglomerate member of the Huckleberry formation. The younger units were only slightly affected.

Aeromagnetic data (U.S. Geological Survey, 1974) suggest that the Deer Trail Group may be underlain by part of a granite pluton that is exposed in the adjacent Waitts Lake quadrangle to the east (F.K. Miller, unpub. mapping, 1979). The scattered mineralization in the stensgar Mountain quadrangle may have been introduced by small hydrothermal systems driven by heat from the pluton.

\section{ANALYTICAL DATA}

In 1980, samples were collected from streams from 41 sites $(41$ silt and 13 pan-concentrate samples) and 66 rock samples were collected from outcrops and mine dumps that contain hematite, pyrite, quartz veins, or other indications of possible alteration such as black iron and manganese oxide staining or bleaching. Sample sites are shown on figure 2 .

The rock and stream-sediment sainples were analyzed for 32 elements (Ag, As, $\mathrm{Au}, \mathrm{B}, \mathrm{Ba}, \mathrm{Be}, \mathrm{Bi}, \mathrm{Ca}, \mathrm{Cd}, \mathrm{Co}, \mathrm{Cr}, \mathrm{Cu}, \mathrm{Fe}, \mathrm{La}, \mathrm{Mg}, \mathrm{Mn}, \mathrm{Mo}, \mathrm{Nb}, \mathrm{Ni}, \mathrm{Pb}, \mathrm{Sb}$, Sc, $S n, S r, T i, T h, V, W, Y, Z n$, and $Z r$ ) by spectrographic methods (Grimes and Marranzino, 1968). The results are reported to the nearest number in the series $1,1.5,2,3,5,7,10$, etc. Precision of reported spectrographic values is plus or minus one step in the series at the 83 -percent confidence level and plus or minus two steps at the 96-percent confidence level (Motooka and Grimes, 1976). Concentrations determined for the major elements (Fe, Mg, $\mathrm{Ca}$, and $\mathrm{Ti}$ ) are given in weight percent; all other concentrations are given in parts per million (ppm). Analysts were R.T. Hopkins and D.J. Grimes of the U.S. Geological Survey. 
Gold analyses of rock, stream-sediment, and panned-concentrate samples by atomic absorption (ward and others, 1969) were performed by C.R. Eaton and A.L. Gruzensky of the U.S. Geological Survey. Atomic absorption mercury analyses of rock and stream-sediment samples (Vaughn and Mccarthy, 1964) were performed by J.D. Sharkey and A.L. Gruzensky of the U.S. Geological survey. Uraniun analyses of rock samples by fluorimetry (Centanni and others, 1956) were performed by L.J. Sherlock of the U.S. Geological Survey.

Table 1 lists the lower limits of determination (reporting value) for each element. The lower limits of determination for gold in atomic-absorption analyses of panned-concentrates are variable (0.05-12.0) and generally higher than for rocks or silt because of the small size of some samples. Table 2 lists the lithologies of the rock samples. Tables 3,4 , and 5 contain the analytical results for rock, stream sediment and panned-concentrate samples, respectively. The letter $\mathrm{N}$ following a number means that the element was not detected at the limit shown; L means that the element was detected but below the lowest reporting value; and $G$, that the concentration of the element exceeded the value shown.

\section{DISCUSSION}

Geochemical sampling was confined largely to the Deer Trail Group south of Huckleberry creek (fig. 2) because glacial till covers much of the northeastern part of the quadrangle and because the Windermere Group and Lower Cambrian rocks to the west are not altered. Outcrops are generally scarce, as the area is covered by thick regolith and dense forest. However, roadcut exposures suggest that there are no broad zones of altered rock in the quadrangle. Except at the wells Fargo mine, mine tunnels in the quadrangle are caved, but mineralized samples are usually available on inine dumps. 
Rocks of the Deer Trail Group contain anomalous quantities of Au, Ag, As, $\mathrm{Ba}, \mathrm{Cu}, \mathrm{Hg}, \mathrm{Mn}, \mathrm{Pb}, \mathrm{Sb}, \mathrm{U}$, and $\mathrm{Zn}$ at threshold values of $0.05,0.5,200$, $1,500,500,0.5,1,500,150,100,0.95$ and $200 \mathrm{ppm}$, respectively. Some uranium values are statistically anomalous but are within normal crustal abundances (Finch and others, 1973, p. 459) and not indicative of uranium enrichment in these rocks.

Exceptionally high values of $\mathrm{Au}(22.4 \mathrm{ppm})$, Ag (70 ppm), As (7,000 ppm), $\mathrm{Pb}(>20,000 \mathrm{ppm}), \mathrm{Sb},(>10,000 \mathrm{ppm})$, and $z i n c(>10,000 \mathrm{ppm})$ occur at the Wells Fargo mine. High values of $\mathrm{Hg}(>10 \mathrm{ppm}), \mathrm{Ag}(2,000 \mathrm{ppm}), \mathrm{Cu}(20,000 \mathrm{ppm}), \mathrm{Pb}$ $(>20,000)$, and $\mathrm{Sb}(3,000 \mathrm{ppm})$ were found at the Double Eagle quarries. Anomalous amounts of $\mathrm{Cu}(20,000 \mathrm{ppm}$ or Inore) were detected at the Edna, Wabash Detroit, and Admiral mines and at two unnamed prospects near the center of section 16 and in the SWl/4 sec. 30, T. 31 N., R. 39 E.. The prospect in section 16 also has high Ag (700 ppm) and As (>10,000 ppm). The prospect in section 30 also nas high in As $(10,000 \mathrm{ppm}), \mathrm{Ba}(5,000 \mathrm{ppm})$, and $\mathrm{Hg}$ (10 ppm). These highly anomalous localities probably are not parts of broad mineralized zones.

Veins rich in $\mathrm{Ag}(15 \mathrm{ppm}$ max), $\mathrm{Ba}(>5,000 \mathrm{ppm}$ max), and lin $(>5,000 \mathrm{ppm}$ max) occur in the southeastern part of the quadrangle. Low gold values (0.1 ppm) and anomalous concentrations of $\mathrm{Ag}$ and $\mathrm{Pb}$ occur in rocks close to the Lane Mountain Thrust. Low gold ( 0.25 ppm) and silver ( 2 ppm) values and anomalous concentrations of $\mathrm{As}, \mathrm{Ba}, \mathrm{Pb}, \mathrm{Sb}$, and $\mathrm{Zn}$ occur in hydrothermally altered dolomite at the Red Marble quarry.

Gold concentrations of 2.6 and 57 ppm were obtained from two pannedconcentrate samples. The lower value is from a sample taken from a branch of the North Fork Deer creek (574) and could reflect gold mineralization near the 
Red Marble Quarry. The higher value is from a sample collected on the North Fork Huckleberry Creek (581). No altered or mineralized rock was observed in this drainage. The gold value possibly reflects leakage of gold-bearing hydrothermal fluids along the fault parallel to Huckleberry creek, but because the mass of the non-magnetic fraction analyzed was very small, the gold value more likely represents a spurious value.

\section{REFERENCES CITED}

Evans, J.G., 1986, Geology of the Stensgar Mountain quadrangle, Stevens County, Washington: U.S. Geological survey Bulletin 1679, 70 p. I in press].

Finch, W.I., Butler, A.P., Jr., Armstrong, F.C., and Weissenborn, A.E., 1973, Uranium, in Brobst, D.A., and Pratt, W.P., eds., United States Mineral Resources; U.S. Geological Survey professional Paper 820, p. 456-468.

Centannim F.A., Ross, A.M., and DeSessa, M.A., 1956, Fluorimetric determination of uranium: Analytical Chemistry, v. 28, p. 1651. Grimes, D.J. and Marranzino, A.P., 1968, Direct-current arc and alternatingcurrent spark emission spectrographic field methods for the semiquantitative analyses of geologic materials: U.S. Geological survey Circular 591, 6 p. Miller, F.K. and Clark, L.D., 1975, Geology of the Chewelah-Loon Lake Area, Stevens and Spokane Counties, Washington: U.S. Geological Survey Professional Paper 806,74 p. Motooka, J.M. and Grimes, D.J., 1976, Analytical precision of one-sixth order semiquantitative spectrographic analysis: U.S. Geological survey Circular $738,25 \mathrm{p}$ 
U.S. Geological Survey, 1974, Aeromagnetic map of parts of the Okanogan, Sandpoint, Ritzville, and Spokane $1^{\circ} \times 2^{\circ}$ quadrangles, northeastern Washington: U.S. Geological Survey Open-File Report 74-1105, scale $1: 250,000$

Vaughn, W.W. and McCarthy, J.H., Jr., 1964, An instrumental technique for the determination of submicrogram concentrations of mercury in soils, rocks, and gas: U.S. Geological Survey Professional Paper 501-D, p. D123-D127.

Ward, F.N., Nakagawa, H.M., Harms, T.F., and Van Sickle, G.H., 1969, Atomic absorption methods of analyses useful in geochemical exploration:

U.S. Geological Survey Bulletin 1289, $45 \mathrm{p}$.

Weaver, C.E., 1920, The mineral resources of Stevens county: Washington Geological Survey Bulletin 20,350 p. 
Table 1.--Lower limits of detection for spectrographic and atomic absorption ( $\mathrm{AU}$ ) analyses. [Values for $\mathrm{Fe}, \mathrm{Mg}, \mathrm{Ca}$, and $\mathrm{Ti}$ are given in weight percent; values for other elements are given in parts per million].

Element

Rock and silt

$\mathrm{Ag}$

Au (spectrographic)

Au (atomic absorption-

rock and stream sediment)

As

B

$\mathrm{Ba}$

$\mathrm{Be}$

$\mathrm{Bi}$

$\mathrm{Ca}$

Cd

Co

$\mathrm{Cr}$

$\mathrm{Cu}$

$\mathrm{Fe}$

La

Mg

$\mathrm{Mn}$

Mo

$\mathrm{Nb}$

$\mathrm{Ni}$

$\mathrm{Pb}$

$\mathrm{Sb}$

Sc

Sn

Sr

Ti

V

W

$Y$

Zn

$2 r$

$\mathrm{Th}$
.5

10

0.05

200

10

. 20

1

10

.05

20

5

10

5

0.05

20

.02

10

5

20

5

10

100

5

10

100

.002

10

50

10

200

10

100 
Sample No.

DAF611

DAF 612

DAF613

DAF614

DAF6 15

DAF 616

DAF 617

DAF 618

DAF 619

DAF 620

DAF 621

DAF 622

DAF 623

DAF 624

DAF 625

DAF 626

DAF 627

DAF 628

DAF 629

DAF 630

DAF631

DAF 632

DAF6 33

DAF 634

DAF 635

DAF 636

DAF 637

DAF 638

DAF 639

DAF 640

DAF641

DAF6 42

DAF 643

DAF 644

DAF 645

DAF 646

DAF 647

DAF 648

DAF 649

DAF 650

DAF6 51

DAF652

DAF 653

DAF65 4 pyritiferous quartz vein

hematitic quartz vein

pyritiferous dolomite

quartz vein with clay pods

guartz vein with vugs

quartz vein with chalcopyrite

guartz vein with zones of black oxides

quartz vein cut by hematite veins

dolomite with hematite staining

silica boxwork with hematite

sericite-quartz vein with pyrite and chalcopyrite

pyritiferous quartz vein

pyrite vein

pyritiferous dolomite (Stensgar dolomite)

pyritiferous quartz vein

pyritiferous quartz vein

pyritiferous and hematitic dolomite (stensgar dolomite)

quartz veins and granitic dikes with pyrite, galena, bornite, azurite, and malachite

hematitic quartzite breccia

quartz vein with yellow oxide staining

malachite veins in dolomite (stensgar Dolomite)

hematitic quartz vein

hematitic quartz vein

quartz vein with black and brown oxide veins

guartzite breccia witn black oxide cement

yellow, brown, and red friable altered siltstone

(Edna Dolomite)

black oxide stained quartz breccia

quartz vein with brown and black oxide staining

quartz vein with black oxide veins

quartz vein with black oxide veins

black oxide veined quartzite (Togo Formation)

hematitic quartz vein

silica boxwork with clay pods

quartz vein with red, brown and black oxide staining

quartz vein with black oxide veins

quartz vein with clay pods

quartz vein with clay pods

quartz vein with brown and black oxide staining

quartz vein with red and black oxide staining

quartz vein with red, brown, and black oxide staining

quartz vein with yellow-brown oxide veins

quartz vein with yellow-brown oxide veins

quartz vein with clay pods

silica boxwork with red and yellow oxides 


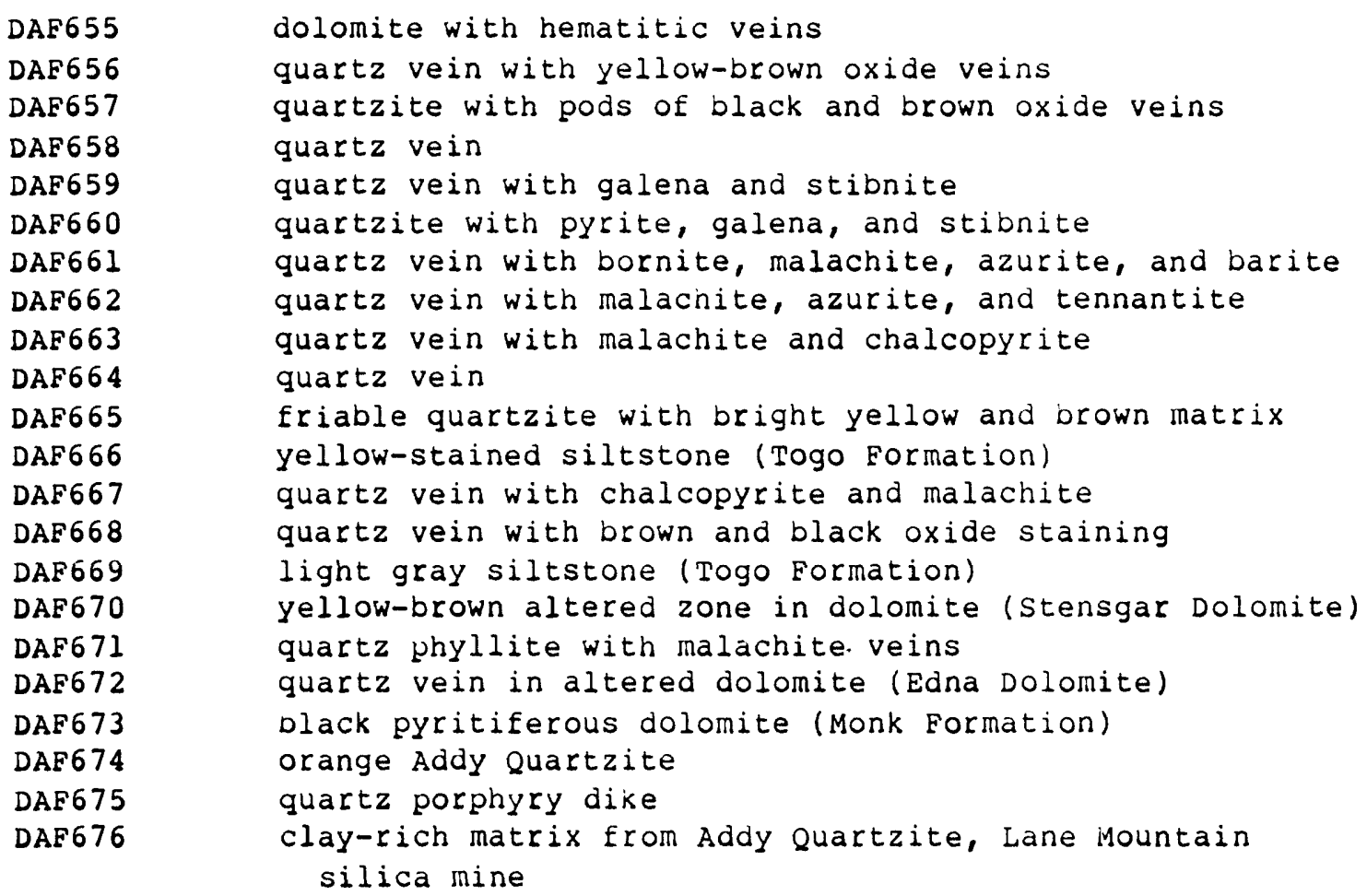

DAF 655

DAF 656

DAF 657

DAF 658

DAF 659

DAF660

DAF661

DAF6 62

DAF 663

DAF664

DAF 665

DAF 666

DAF 667

DAF 668

DAF 669

DAF 670

DAF 671

DAF 672

DAF 673

DAF 674

DAF 675

DAF 676

dolomite with hematitic veins

quartz vein with yellow-brown oxide veins

quartzite with pods of black and brown oxide veins

quartz vein

quartz vein with galena and stibnite

quartzite with pyrite, galena, and stibnite

quartz vein with bornite, malachite, azurite, and barite

quartz vein with malacnite, azurite, and tennantite

quartz vein with malachite and chalcopyrite

quartz vein

friable quartzite with bright yellow and brown matrix

yellow-stained siltstone (Togo Formation)

quartz vein with chalcopyrite and malachite

quartz vein with brown and black oxide staining

light gray siltstone (Togo Formation)

yellow-brown altered zone in dolomite (Stensgar Dolomite)

quartz phyllite with malachite. veins

quartz vein in altered dolomite (Edna Dolomite)

black pyritiferous dolomite (Monk Formation)

orange Addy Quartzite

quartz porphyry dike

clay-rich matrix from Addy quartzite, Lane Mountain

silica mine 


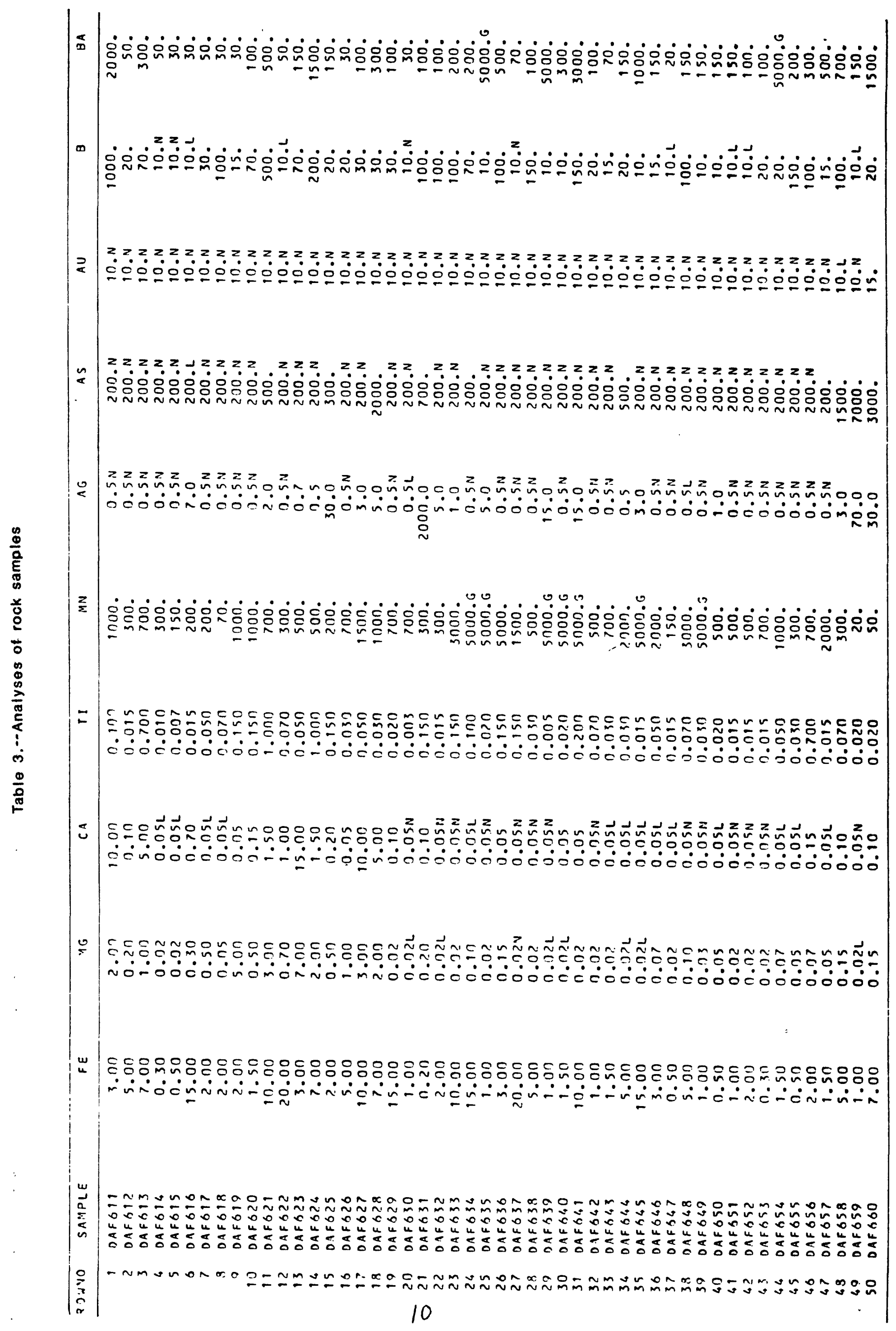




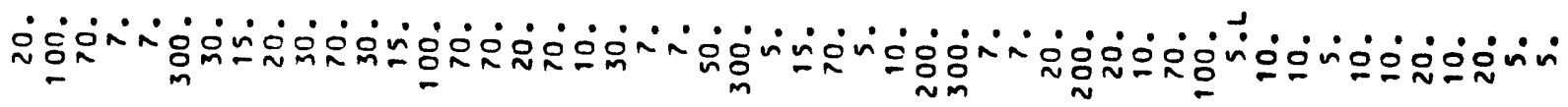

$z z z z z z z z z z z z z z z z z z z z z z z z z z z z z z z z z z z z z z z z z z z z z z z z z z$

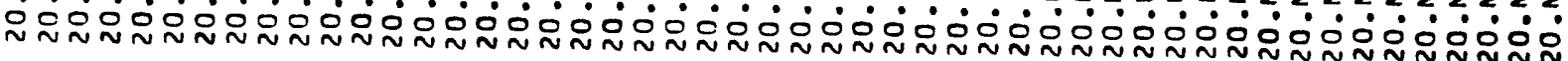

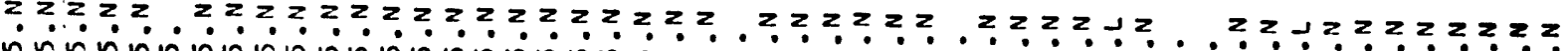

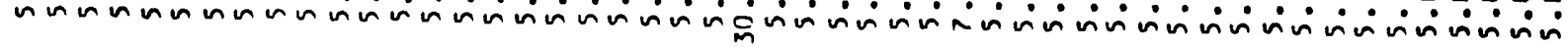

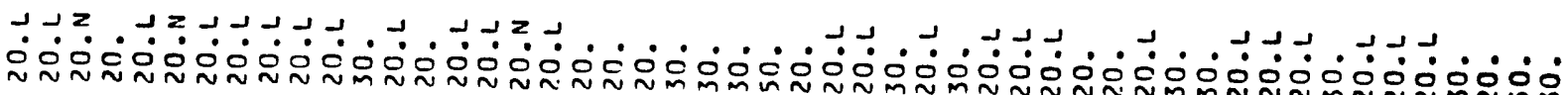
(1)

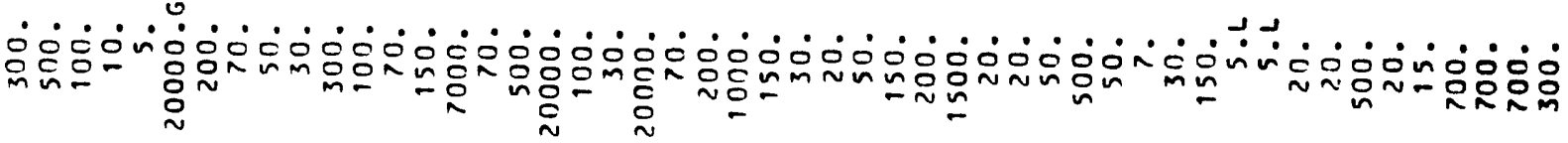

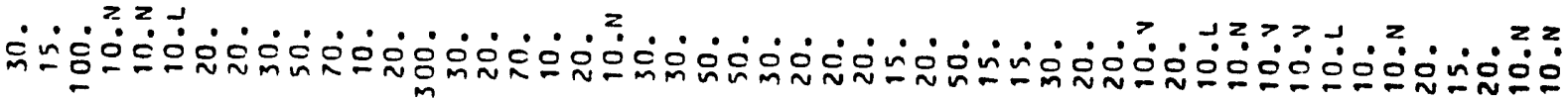

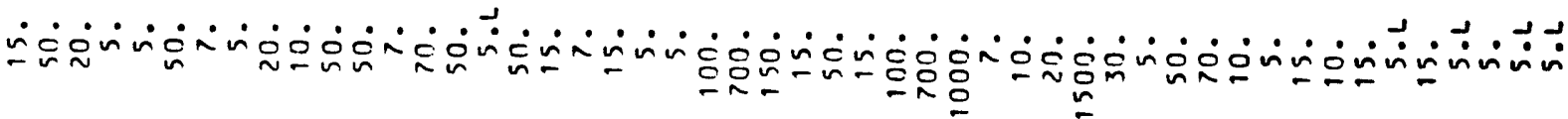

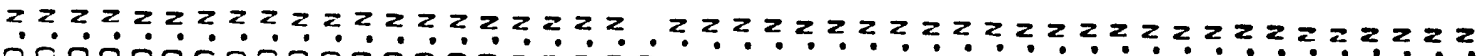

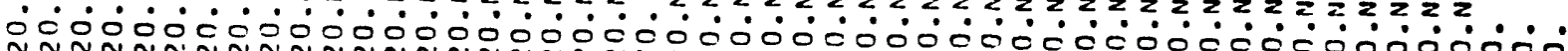
-

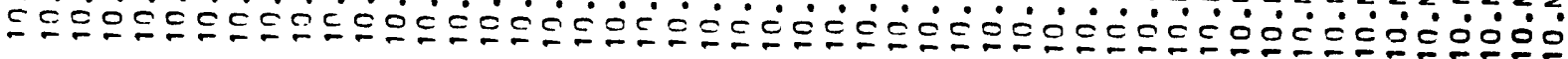

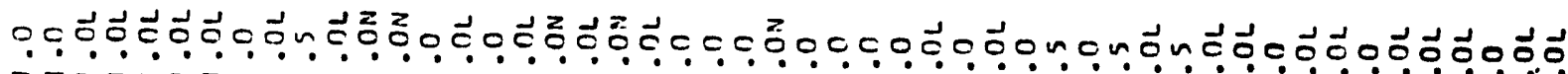

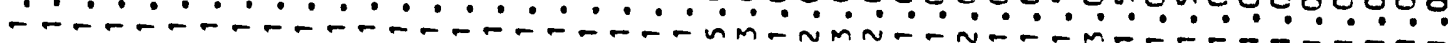

u.

ニ

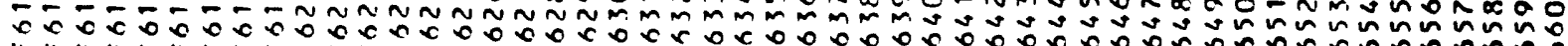

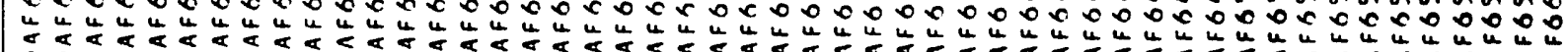

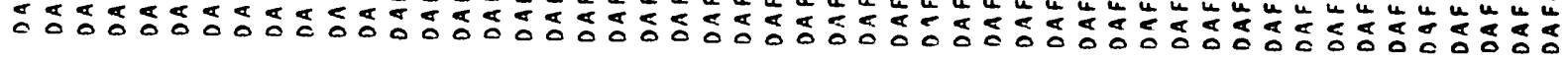




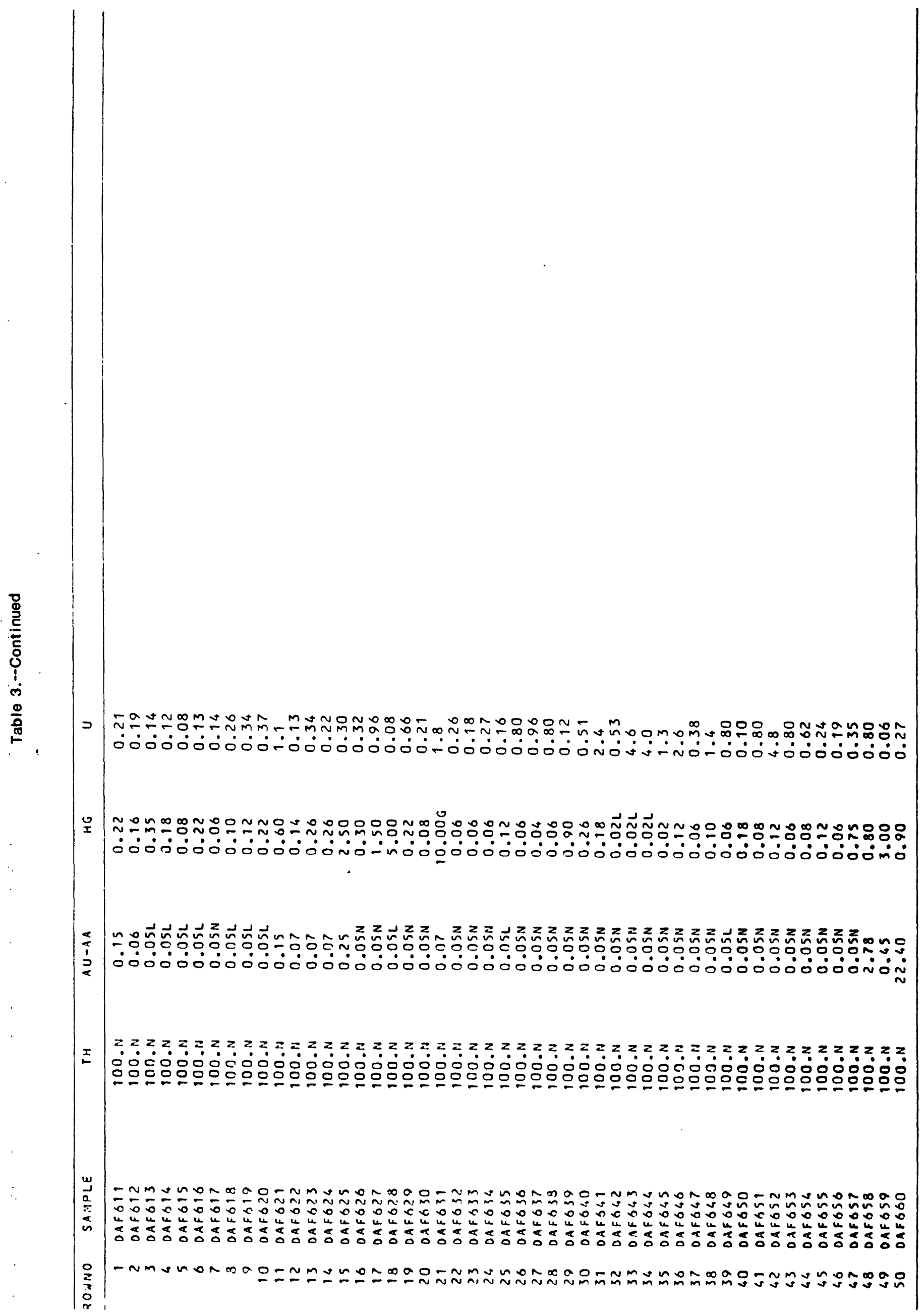




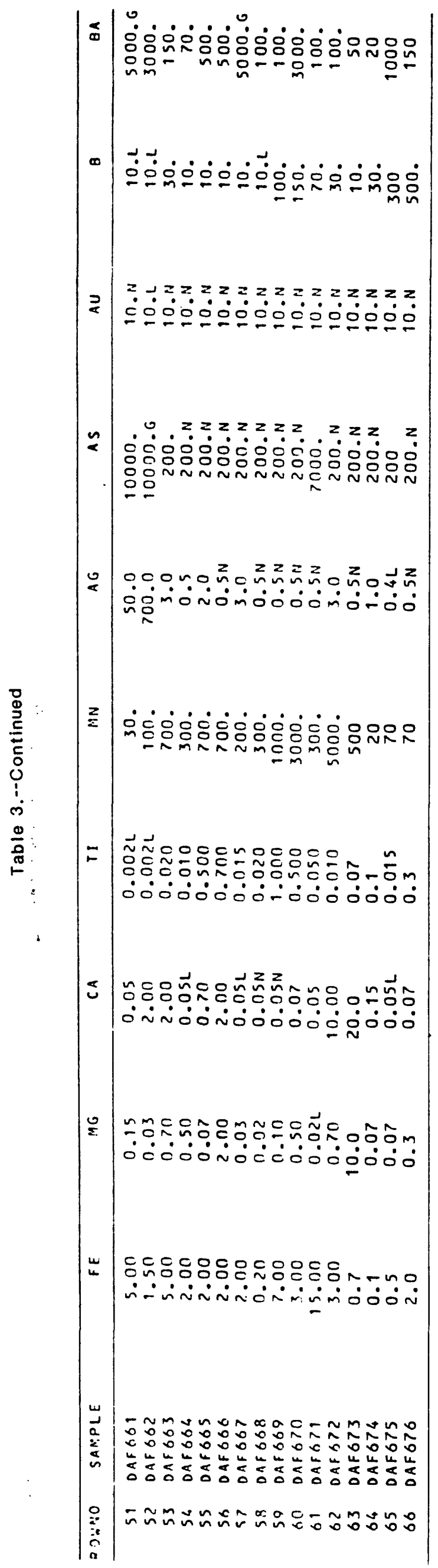




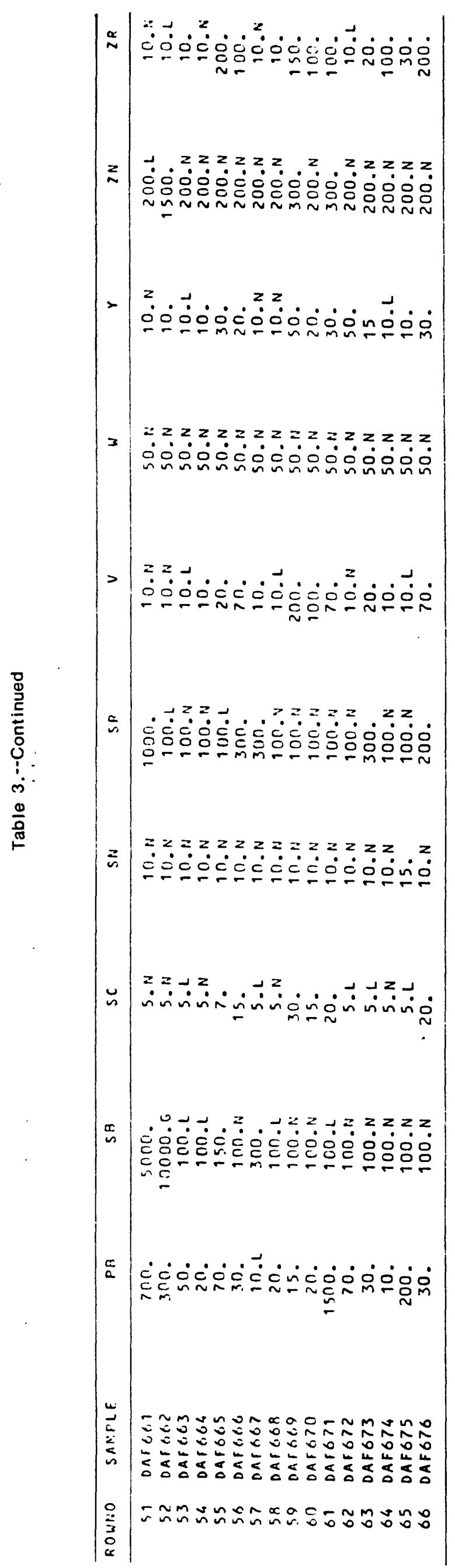




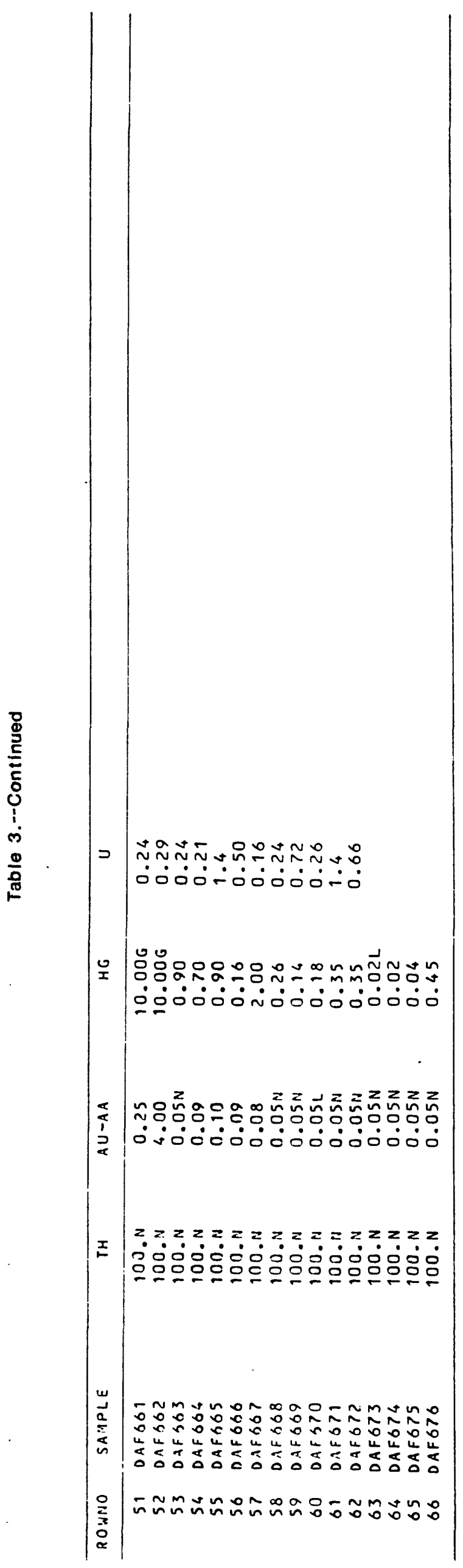




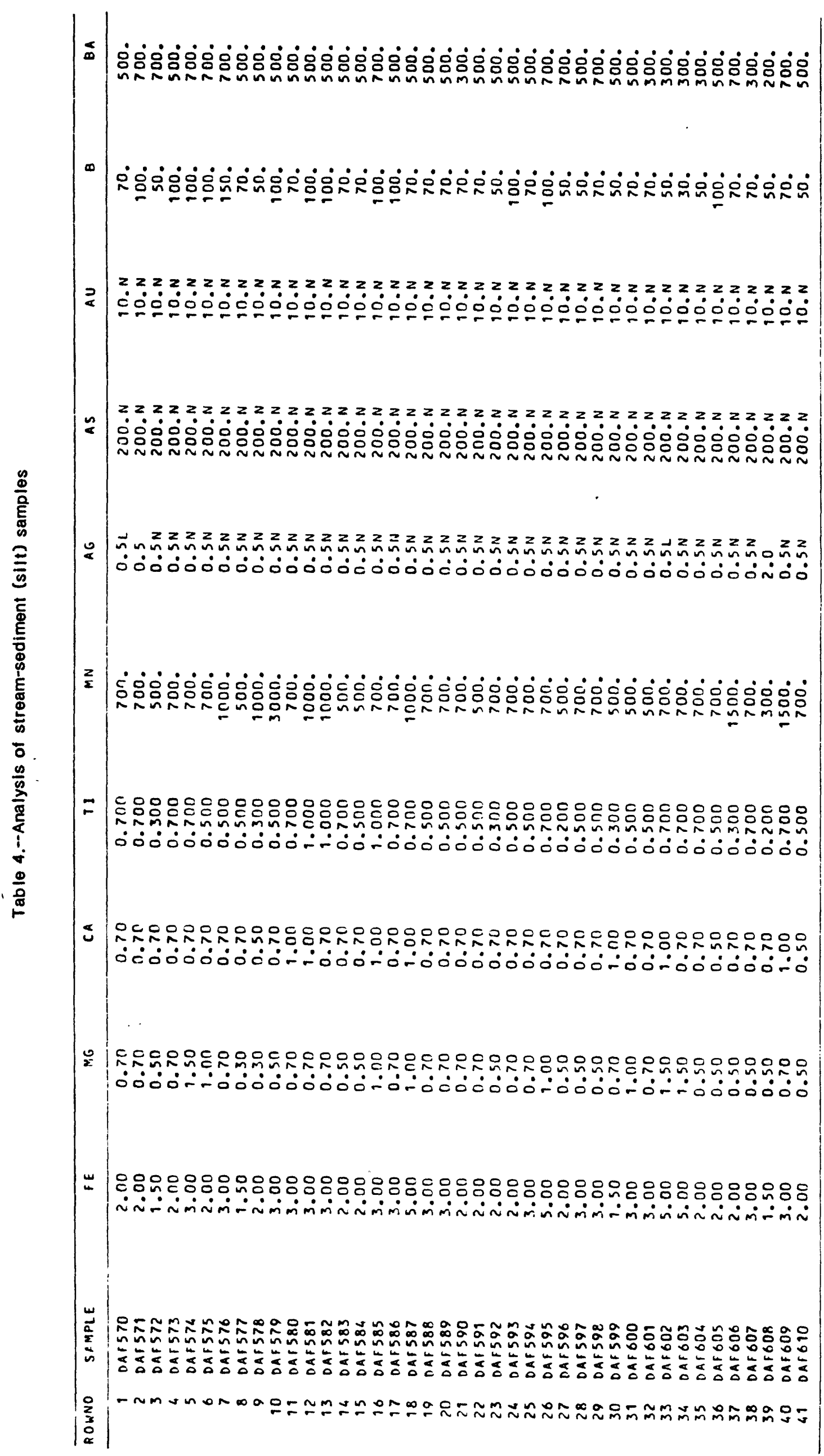




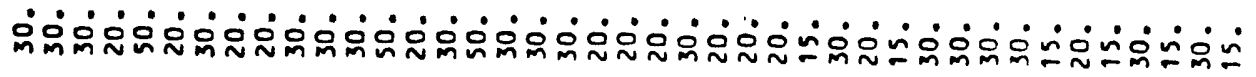

zzzzzzzzzzzzzzzzzzzzzzzzzzzzzzzzzzzzzzzz i

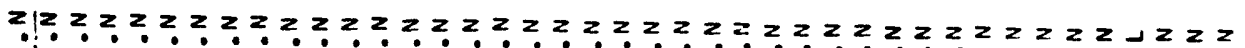

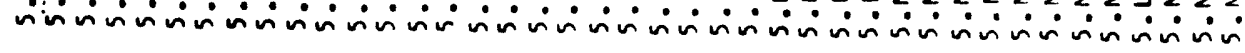

mm

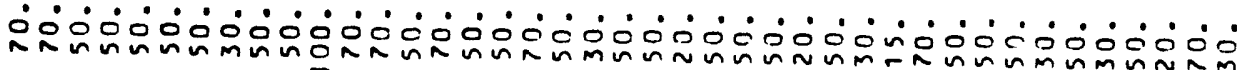

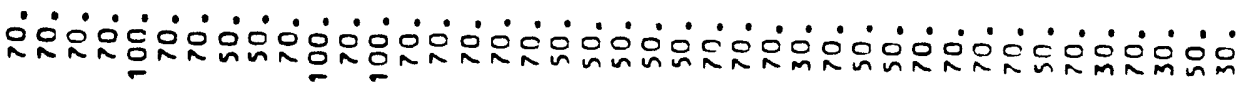

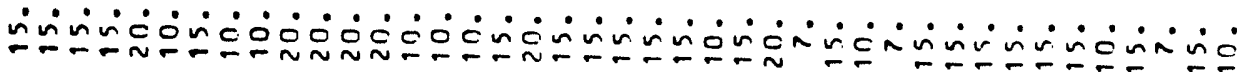

zzzzzzzzzzzzzzzzzzzzzzzzzzzzzzzzzzzzzzz i

zzzzzzzzzzzzzzzzzzzzzzzzzzzzzzzzzzzzzzzzz

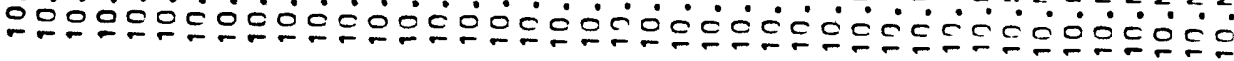

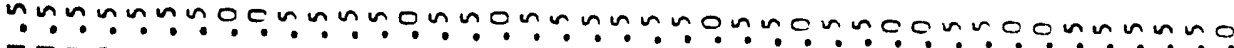
-

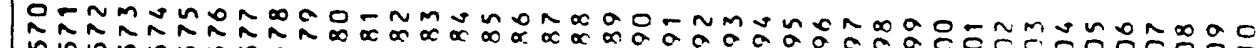

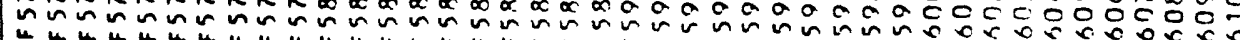

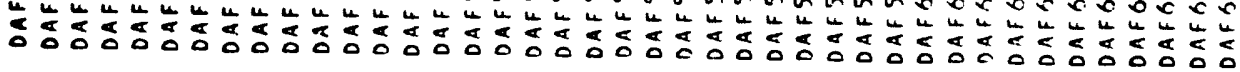

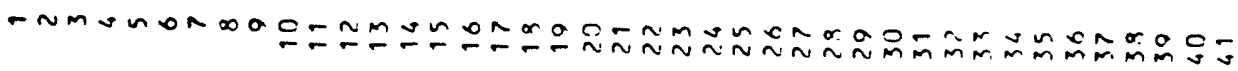




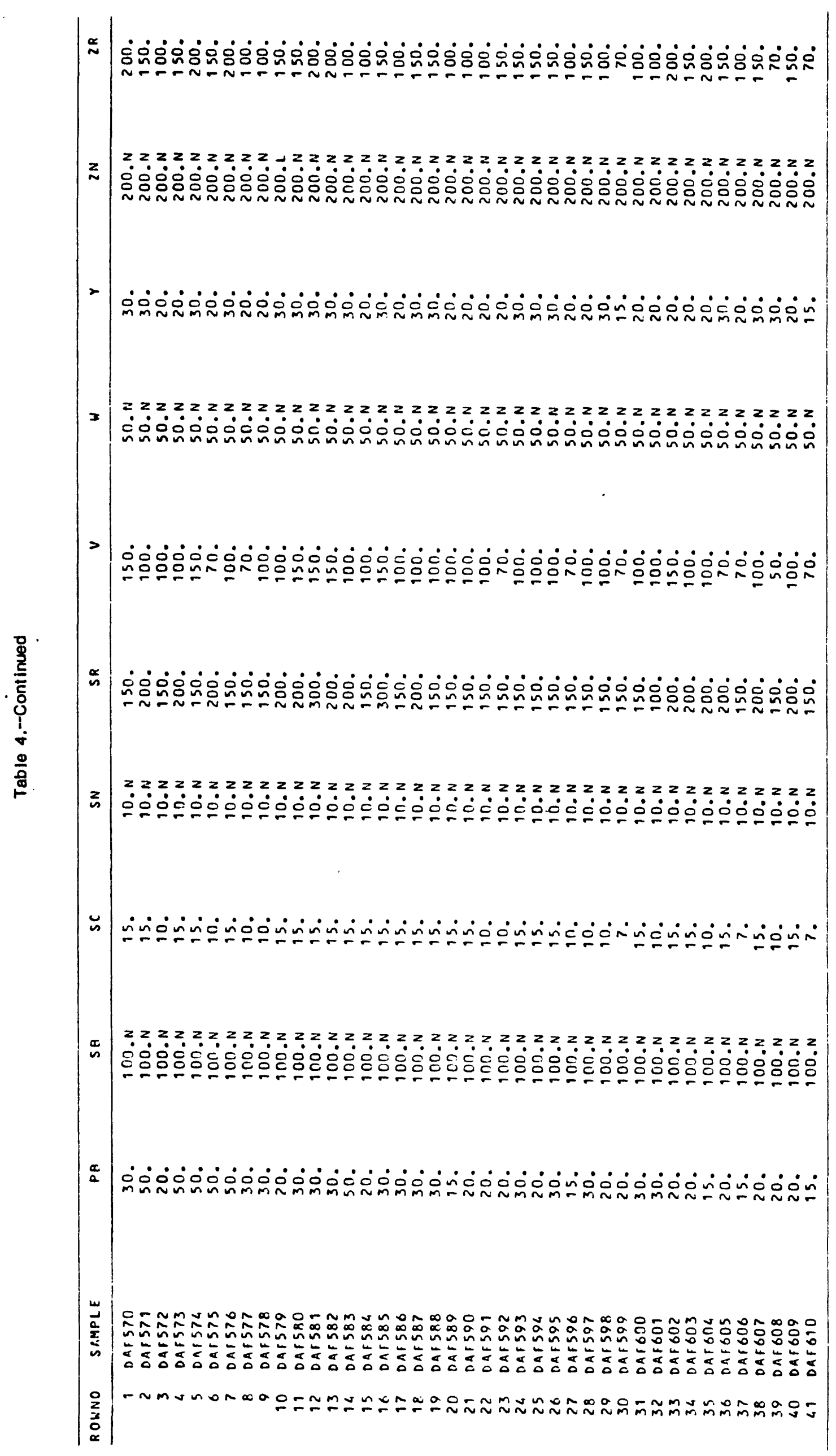




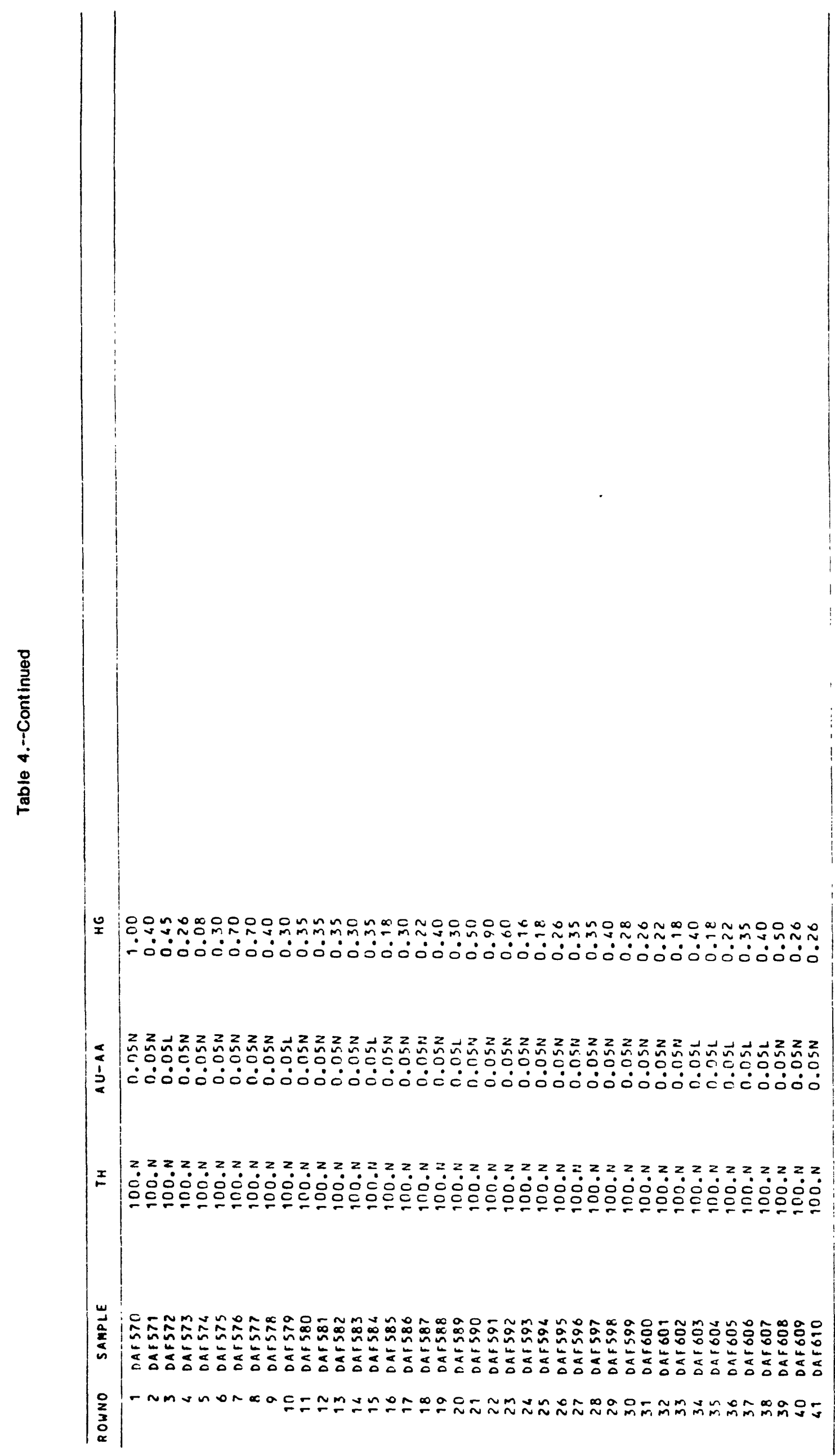


TABLE 5.--Gold analyses of pan-concentrate samples

\begin{tabular}{|c|c|c|c|c|c|c|}
\hline \multirow{2}{*}{$\begin{array}{l}\text { Sample } \\
\text { Number }\end{array}$} & \multicolumn{2}{|c|}{ Magnetic fraction } & \multicolumn{2}{|c|}{ Para-magnetic } & \multicolumn{2}{|c|}{ Non-inagnetic fract } \\
\hline & $\mathrm{Au}$ & $\begin{array}{c}\text { Sample wt. } \\
\text { in grams }\end{array}$ & Au & $\begin{array}{c}\text { Sample wt. } \\
\text { in grams }\end{array}$ & $\mathrm{Au}$ & $\begin{array}{l}\text { Sample } \\
\text { in gra }\end{array}$ \\
\hline DAF570 & $0.12 \mathrm{~N}$ & 4.02 & $0.05 \mathrm{~N}$ & 10.00 & $10.00 \mathrm{~N}$ & 0.05 \\
\hline DAF571 & $0.05 \mathrm{~N}$ & 10.00 & $0.05 \mathrm{~N}$ & 10.00 & $1.90 \mathrm{~N}$ & 0.26 \\
\hline $\begin{array}{l}\text { DAF572 } \\
\text { DAF573 }\end{array}$ & $\begin{array}{l}0.08 \mathrm{~N} \\
0.09 \mathrm{~N}\end{array}$ & $\begin{array}{l}6.10 \\
5.36\end{array}$ & $\begin{array}{l}0.05 \mathrm{~N} \\
0.05 \mathrm{~N}\end{array}$ & $\begin{array}{r}9.40 \\
10.00\end{array}$ & $\begin{array}{l}0.60 \mathrm{~N} \\
0.90 \mathrm{~N}\end{array}$ & $\begin{array}{l}0.84 \\
0.55\end{array}$ \\
\hline DAF 574 & $0.27 \mathrm{~N}$ & 1.88 & $0.08 \mathrm{~N}$ & 5.93 & 2.60 & 0.38 \\
\hline DAF 575 & $0.10 \mathrm{~N}$ & 5.09 & $0.05 \mathrm{~N}$ & 9.20 & $0.55 \mathrm{~N}$ & 0.93 \\
\hline DAF576 & $0.10 \mathrm{~N}$ & 4.96 & $0.07 \mathrm{~N}$ & 6.95 & $3.10 \mathrm{~N}$ & 0.16 \\
\hline DAF 578 & $0.14 \mathrm{~N}$ & 3.45 & $0.05 \mathrm{~N}$ & 9.88 & $4.50 \mathrm{~N}$ & 0.11 \\
\hline DAF580 & $0.36 \mathrm{~N}$ & 1.40 & $0.05 \mathrm{~N}$ & 10.00 & $0.45 \mathrm{~N}$ & 0.11 \\
\hline DAF581 & $0.11 \mathrm{~N}$ & 4.45 & $0.05 \mathrm{~N}$ & 10.00 & 57.00 & 0.28 \\
\hline DAF582 & $0.17 \mathrm{~N}$ & 2.88 & $0.05 \mathrm{~N}$ & 10.00 & $3.60 \mathrm{~N}$ & 0.14 \\
\hline DAF587 & $0.05 \mathrm{~N}$ & 10.00 & $0.05 \mathrm{~N}$ & 10.00 & $4.50 \mathrm{~N}$ & 0.11 \\
\hline DAF591 & $0.23 \mathrm{~N}$ & 2.15 & $0.05 \mathrm{~N}$ & 9.21 & $12.00 \mathrm{~N}$ & 0.05 \\
\hline
\end{tabular}




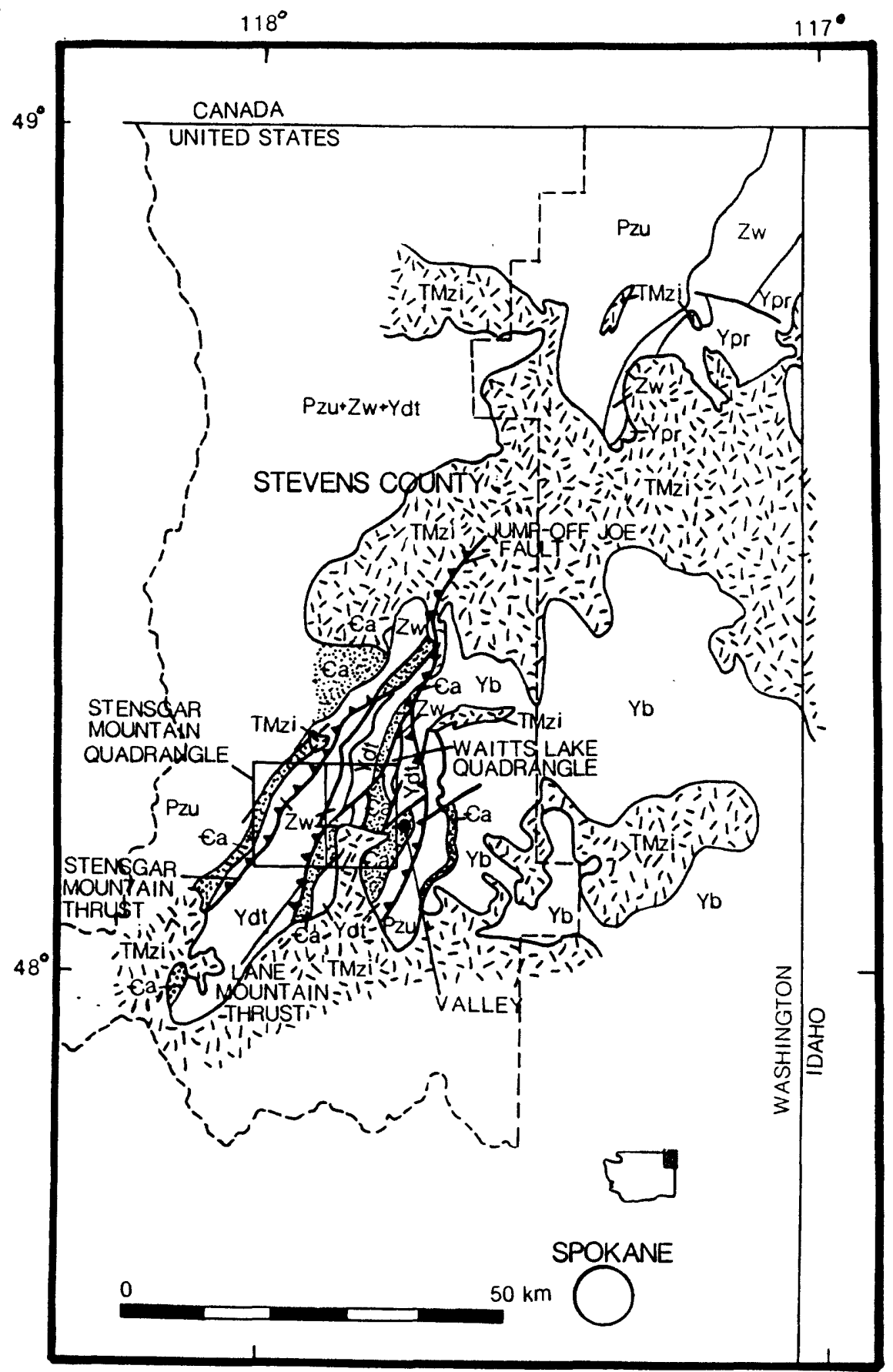

Figure 1. Index map showing major geologic units and structures in northeast Washington (modified from Miller and Clark, 1975, fig. 8). TMzi. Tertiary and Mesozoic rocks; Pzu, Paleozoic rocks, undivided; Ea, Addy Quartzite; Zw, Windermere Group; Ydt, Deer Trail Group; Ypr, Priest River Group; Yb, Belt Supergroup. 


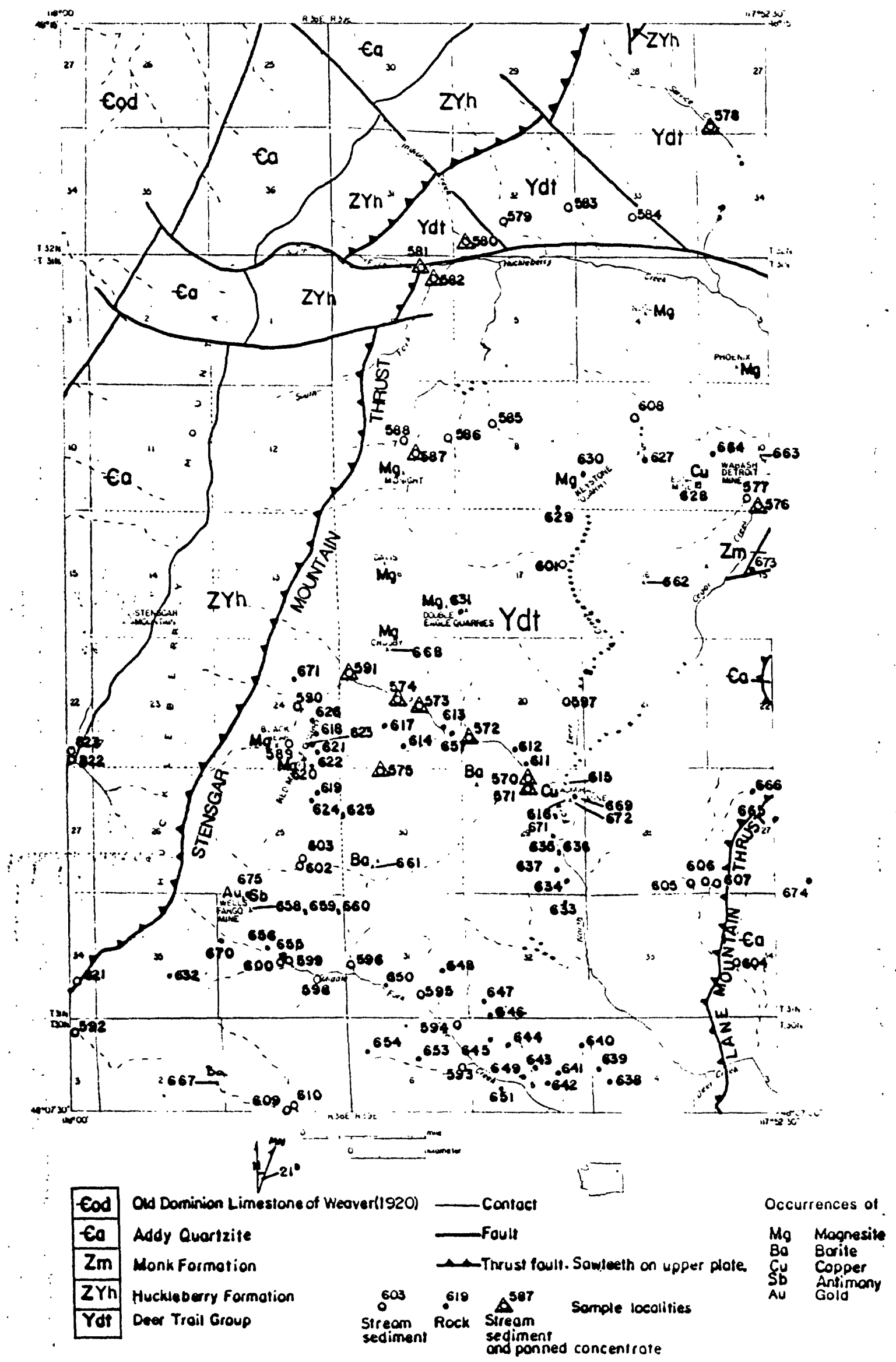

Figure 2. Ceneralized geologic map of the Stensgar Mountain quadrangle snowing locallties and occurences of magnesile, barite, copper. antimony, and gold. Sample numbers are preceded by DAF in rables. 